\title{
RATING METHODOLOGY FOR REAL ESTATE MARKETS - POLAND CASE STUDY
}

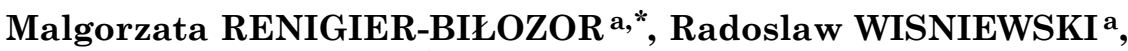 Arturas KAKLAUSKAS ${ }^{\text {b }}$, Andrzej BILOZOR ${ }^{c}$}

${ }^{a}$ Department of Real Estate Management and Regional Development, Faculty of Geodesy and Land Management, University of Warmia and Mazury in Olsztyn, Prawochenskiego 15, 10-724 Olsztyn, Poland

${ }^{b}$ Department of Construction Economics and Property Management, Vilnius Gediminas Technical University, Sauletekio al. 11, LT-10223 Vilnius, Lithuania

${ }^{c}$ Department of Cadastre and Spatial Management, Faculty of Geodesy and Land Management, University of Warmia and Mazury in Olsztyn, Poland

Received 1 July 2013; accepted 21 March 2014

\begin{abstract}
The development of the real estate market is conditioned by a variety of endogenous and exogenous factors. Selected factors determine the local character of the real estate market, whereas others contribute to its classification as one of the main branches of the national economy. Rapid economic growth and the search for new investment opportunities have turned the real estate market into a highly competitive arena where various players carry out diverse investment strategies. Investors search for similarities that would enable them to develop risk minimizing strategies. Ratings are a modern tool that can be deployed in analyses and predictions of real estate market potential. This paper proposes a methodology for developing real estate market ratings, and it identifies the types of information and factors which affect decision-making on real estate markets. The following research hypotheses are formulated and tested in the article: 1) a real estate market can be rated in view of its significance for the local and national economy, 2) real estate market ratings support market participants in the decision-making process.
\end{abstract}

KEYWORDS: Real estate market; Real estate market ratings; Decision-making process; Credit ratings; Rating methodology

REFERENCE to this paper should be made as follows: Renigier-Biłozor, M.; Wisniewski, R.; Kaklauskas, A.; Biłozor, A. 2014. Rating methodology for real estate markets - Poland case study, International Journal of Strategic Property Management 18(2): 198-212.

\section{INTRODUCTION}

"Rating" is an economic term with a variety of meanings. In the discussed context, a rating encompasses the process and the results of evaluation and classification of a given phenomenon. Ratings are performed by credit rating agencies (CRA) as well various institutions which use ratings for their own needs, mostly banks, investment funds and insurance companies. A credit rating is a system for evaluating and classifying investment risk. Outside the capital market, ratings are used

\footnotetext{
* Corresponding author. E-mail: malgorzata.renigier@uwm.edu.pl
}

to assess phenomena and processes which are unrelated to investments.

Ratings are developed for a wide range of market entities, including local businesses, organizations, universities, public utilities (such as hospitals), cities, investment funds, international businesses and national economies. Credit ratings evaluate the performance of various market actors based on a set of standard evaluation criteria. They support decision-making in a homogenous environment, thus minimizing investment risk and increasing the safety of capital investments. 
Credit ratings enjoy growing popularity as a vital source of information about the risk of bankruptcy, performance and financial standing of the analyzed entity (such as the national economy). Rating scores are published, and they affect the performance of the evaluated entities (economies) in the domestic and international arena. CRAs and the published ratings play a very important role for investors who can use the available information to verify the financial standing of a given entity. The evaluated entities' responses to the data published by CRAs also provide valuable inputs for investors, which further attests to credit ratings' significance for the market. Credit ratings have a huge influence on the contemporary market, and they can deliver market-creating effects.

After September 2008, real estate markets around the world have been haunted by the specter of a financial crisis, in particular a public finance crisis (growing public debt). Theoretically, real estate markets should have a delayed response to macroeconomic events and relevant political decisions (Wiśniewski 2007). However recent developments in the global economy have shown that they (similarly to other more liquid assets) not only imitate general economic trends, but can actually cause them. D'Arcy and Keogh (1999) believe that an institutional analysis of individual urban property markets offers a valuable means of understanding the way in which property market outcomes affect the competitive performance of the wider urban economy. The institutional structure of the property market determines its ability to accommodate the pressure for change in the urban economy.

Interestingly enough, contemporary real estate markets have been found to respond more flexibly to macroeconomic changes. Those responses are driven not only by changes in the real estate sector, but mostly by macroeconomic and microeconomic data coming from other markets.

Investors bring large sums of capital into real estate markets around the world. It is generally known that real estate markets attract growing numbers of investors in a crisis. Today's markets are increasingly stressed by turbulent events of various magnitude, which implies that they should be evaluated with the use of professional tools. Kaklauskas et al. (2011) argue that one of the macro-level recommendations for construction and real estate crisis management is reduction of the psychological tension and panic related to coming crisis and new methods must be developed for crisis forecasting and modeling. Credit ratings offer such a tool.
This paper comprises six chapters. Chapter 2 is a literature review, chapter 3 discusses the objectives and functions of real estate market ratings, chapter 4 proposes a methodology for rating real estate markets, chapter 5 discusses rating results, chapter 6 presents results, and the relevant conclusions are formulated in chapter 7 .

\section{LITERATURE REVIEW}

\subsection{CRA ratings}

Inaccurate and delayed ratings have provoked a discussion about the reliability of credit rating agencies and the adopted methodological standards. Critical events which sparked this debate included the collapse of the Lehmans Brothers bank and credit rating agencies' tardiness in downgrading Greek or Italian economies. CRAs have been criticized by Altman and Saunders (2001) and Altman and Rijken (2004) who argued that credit ratings fail to account for critical information, focus mostly on past events and make long-term forecasts based on short-term prediction models (e.g. annual). According to Caporale et al. (2012), credit ratings issued in a crisis situation (when they are most useful) are highly inaccurate and unreliable.

Despite delayed and inaccurate predictions, credit ratings are a highly effective analytical tool. Scoring systems offer a standardized approach to comparing the credit worthiness of various market entities. Credit ratings are a source of normalized and, in principle, unbiased information. In this context, the establishment of separate credit rating agencies by national governments seems to be a misguided concept. The strength of credit rating agencies comes from their independence from the organizations they rate. The independent and objective nature of CRAs has been recognized and emphasized by EU law (Regulation (EC) No. 1060/2009 of the European Parliament and of the Council of 16 September 2009 on credit rating agencies; Commission Delegated Regulation (EU) No. 447/2012 of 21 March 2012 supplementing Regulation (EC) No. 1060/2009 of the European Parliament and of the Council on credit rating agencies by laying down regulatory technical standards for the assessment of compliance of credit rating methodologies). Nationalized credit rating agencies may be a less reliable source of information for investors, and as such, they will no longer serve their original purpose. CRAs operate on various markets and within various reference frameworks. The big three credit rating agencies - Fitch 
Ratings, Moody's and Standard \& Poor's - are USbased, and they have the status of Nationally Recognized Statistical Rating Organizations. At the domestic level, independent agencies operate on a much smaller scale than international organizations.

Credit rating firms apply different rating procedures, and some analyses and decision-making processes are confidential. Selected data is kept confidential due to market competition, but this lack of transparency could jeopardize the reliability and impartiality of rating scores.

To unify their scores, credit rating agencies use a 20-point rating scale developed by John Moody in 1909. Ratings are divided into two primary categories: investment grade (AAA, AA, A, BBB) and speculative grade $(\mathrm{BB}, \mathrm{B}, \mathrm{CCC}, \mathrm{CC}, \mathrm{C}, \mathrm{DDD}, \mathrm{DD}$, D). Plus (+) and minus (-) signs may be appended to rating symbols to indicate their relative position within each rating category. Both investmentgrade and speculative-grade ratings are important for investors. Investment-grade securities are characterized by low risk and lower return rates, whereas speculative-grade securities have higher yields (higher interest rates) and a higher risk of default. CRAs further modify their rating symbols to provide both credit and non-credit ratings (www.moodys.com, www.fitchpolska.com, www. standardandpoors.com).

In most CRAs, the rating process takes place at two levels. Information about the evaluated entity is analyzed and processed with the involvement of various statistical methods. The entity's credit worthiness is assessed based on quantitative and qualitative analyses.

\subsection{Real estate market ratings}

On the real estate market, several concepts are related to, but do not constitute a market rating. They complement rating scores or provide alternative tools for evaluating market performance. In this context, the concepts of market classification, taxonomy, segmentation and ranking are often incorrectly used. Markets are generally classified in view of the type of traded estate (land plots, buildings, apartments), parties to the transaction (local government, central authorities, individuals), type of real estate (residential, commercial, industrial, recreational, agricultural) and geographic reach (local, supralocal, regional, national, international). Taxonomy and segmentation imply detailed classification of real estate markets, based on the preferences of specific buyer groups, into sub-markets, such as class A or class B office space or residential housing. Goodman and Thibodeau (1998, 2003) classified residential property based on criteria such as spatial variation, neighborhood and physical attributes.

The term "ranking" is often used interchangeably with "rating", but the two concepts are not synonymous. According to Dziawgo (2010), in a ranking process, the analyzed elements are allocated to respective segments and are grouped without being ranked in a given order within the segment. A rating, on the other hand, provides market actors with additional information about the credit worthiness and performance of a given market, the quality of market processes and the consequences of decisions made by market entities. In this respect, the real estate market does not differ from other markets which are evaluated by credit rating agencies.

The specificity of the real estate market is determined by the unique attributes of property. For this reason, rating methodologies applied on capital markets cannot be simply copied to the real estate market. Comprehensive methodologies for classifying real estate markets have not yet been proposed in Poland or Europe. Attempts have been made to rate real estate businesses (real estate agencies, investment firms) (Milewski 1999; Pierwszy Ranking Firm ... 2004) or rank individual properties which are valuable in a given investment project (CRISIL 2011).

The global classification of real estate markets using a transparency index provided by Jones Lang LaSalle (2012) (http://www.joneslanglasalle. com) is really worth mentioning. The 2012 Global Real Estate Transparency Index (first published in 1999), which calculates transparency in 97 (e.g., with Poland at a high 19th position) real estate markets worldwide by weighting 83 different factors, provides investors and corporate occupiers with data and analyses critical to transacting, owning and operating in global markets. The Index also assists governments and other industry organizations interested in improving transparency. These 83 factors are grouped into 13 topic areas which are further grouped into five subindex categories - a) performance measurement, b) market fundamentals c) governance of listed vehicles d) regulatory and legal and e) transaction process. A Composite Index for each market is created from the weighted scores of the 83 factors. The scores range on a scale from 1.0 to 5.0. A country or market with a perfect score of 1.0 has total real estate transparency, whereas a country with a score of 5.0 is characterized by total real estate 
opacity. Countries/markets are assigned to a one of five transparency levels, ranging from HighlyTransparent, Transparent and Semi-Transparent to those of Low-Transparency or even Opaque (Jones Lang LaSalle 2012). From the overall point of view, the transparency index can be interpreted as the access to general and crucial information about real estate, such as: the existence and types of indices, independence, quality and frequency of third-party appraisals, the existence and length of time series on property rents, vacancy or quality, and the availability of pre-sale information.

A pioneering solution for rating real estate markets was proposed at the TEGoVA's EVS conference in Warsaw 2012 by Kalberer (2012) in The future of risk analysis in valuation: property and market rating. In the above study (initially designed by Trotz, 2004), the real estate market was classified based on a double weighted matrix. The cited elaboration identified high-risk markets (where threats exist) and markets with a growth potential (where opportunities exist). Weights were allocated subjectively based on a set of general criteria, including real estate, location, market, quality of cash flows, as well as detailed criteria which contribute additional information to general criteria. Market indicators were divided into macroeconomic and microeconomic factors, including acts of God, socio-demographic development, overall economic development and international attractiveness, political, legal and monetary condition, property market, residential property.

Real estate market ratings serve a variety of practical purposes. They are used to develop portfolio strategies (Anglin, Gao 2011; Collett et al. 2003) and formulate long-short portfolio strategies on housing indices for more risky and less risky assets characterized by low liquidity (Beracha, Skiba 2011). The scarcity of relevant information results from the shortcomings of market effectiveness analyses (Case, Shiller 1989; Fama 1991; Grossman, Stiglitz 1980; Kaklauskas et al. 2011; Renigier-Biłozor, Wisniewski 2012a; Źróbek, Grzesik 2013). According to Case and Shiller (1989, 1990), the ineffectiveness of the analyzed market can be attributed to individual investors who do not have access to objective knowledge about the real estate market. Although the results of the levels of market maturity analysis indicate (Chin, Dent 2005) that investors still focus their principal analysis of investment opportunities on general economic indicators, their interest and understanding of the specific factors influencing property performance appear to be very much secondary in the decision making process.

\section{OBJECTIVES AND FUNCTIONS OF REAL ESTATE MARKET RATINGS}

The main objective of real estate market ratings is to create a universal and standardized classification system for evaluating the real estate market. A rating system contributes to objectivity in the decision-making process and it shortens decisionmaking time.

The detailed objectives of developing scoring systems for real estate markets are:

- to introduce objective benchmarks for comparing real estate markets,

- to contribute to the rationality of the decision-making process,

- to reduce the number of variables in the decision-making process,

- to evaluate real estate markets' potential for economic and spatial growth,

- to determine the effectiveness of real estate investments (return on real estate investments),

- to predict the performance of the real estate market,

- to predict threats to market growth, including stagnant periods, demand-supply imbalances and real estate prices,

- to evaluate social benefits/losses resulting from the development of a given real estate market,

- to identify market behaviors,

- to provide for effective flow of information about the real estate market,

- to minimize the negative impacts of "television experts" whose comments are based on unverifiable and often incidental reports about real estate market activity,

- to modulate the behavior of real estate market actors.

Real estate market ratings have the following functions:

- information function - decision makers are provided with reliable, comprehensive and transparent information about real estate,

- equal opportunities function - ratings are published in publicly available journals, magazines and on websites to enable both professionals and non-professionals to make reliable decisions on the real estate market,

- rationalizing function - uninhibited information flow contributes to effective and rational decision-making on the real estate market by reducing the number of decision variables for both professional and non-professional market actors, 
- organizational function - redundant, erroneous and false information is eliminated to reduce noise on the real estate market,

- propagating function - information about real estate markets is popularized,

- "manipulative" function - ratings affect market participants' behavior and attitudes towards real estate.

Every rating is developed for a broad group of recipients who have varied levels of knowledge about the analyzed real estate market. A rating scale for classifying real estate markets is proposed in Table 1.

In Table 1, real estate markets are scored on a 10-point rating scale and are divided into four rating level groups: investment, development, stagnant and crisis. Except for the crisis level group which has a single score $-D$, there are three scores per each group: $\mathrm{AAA} / \mathrm{BBB} / \mathrm{CCC}, \mathrm{AA} / \mathrm{BB} / \mathrm{CC}$ and
$\mathrm{A} / \mathrm{B} / \mathrm{C}$. Scores AAA/BBB/CCC represent the highest rating, $\mathrm{AA} / \mathrm{BB} / \mathrm{CC}$ - a medium rating, and $\mathrm{A} / \mathrm{B} / \mathrm{C}$ - the lowest rating in a given group. Plus $(+)$ and minus (-) signs may be appended to rating symbols to indicate their relative position within each group.

A rating system for the real estate market and its participants will:

- increase the safety of market transactions,

- improve the efficiency of the real estate market,

- stabilize prices on the real estate market,

- improve the effectiveness of the decisionmaking process,

- lower mortgage interest rates and improve mortgage availability,

- increase local authorities' sensitivity to regional development and stimulate the real estate market,

Table 1. Rating scale for classifying real estate markets

\begin{tabular}{|c|c|c|}
\hline Group & Rating scale & Description of risks \\
\hline $\begin{array}{l}\text { Investment } \\
\text { level }\end{array}$ & $\mathrm{AAA}$ & $\begin{array}{l}\text { High return on investments. } \\
\text { Positive market outlook. } \\
\text { High market growth potential (supply and demand on the real estate market). } \\
\text { High potential for economic and spatial growth. } \\
\text { Self-regulatory capacity, flexible response to economic changes. } \\
\text { The situation on the real estate market fosters positive social change. } \\
\text { Satisfactory price-cost relationship. } \\
\text { Stable behavior of real estate market actors. } \\
\text { Low threats to the growth of the real estate market. The situation on real estate market } \\
\text { fosters positive social change. }\end{array}$ \\
\hline $\begin{array}{l}\text { Development } \\
\text { level }\end{array}$ & $\mathrm{BBB}$ & $\begin{array}{l}\text { Moderate return on investments. } \\
\text { Moderate market outlook. } \\
\text { Certain threats to market growth potential (supply and demand on the real estate market). } \\
\text { Moderate potential for economic and spatial growth. } \\
\text { Lower self-regulatory capacity, less flexible response to economic changes. } \\
\text { The situation on the real estate market fosters moderately positive social change. } \\
\text { Greater discrepancies between the cost and prices of real estate. } \\
\text { Less predictable behavior of real estate market actors. } \\
\text { Moderate threats to the growth of the real estate market. } \\
\text { The situation on the real estate market fosters moderately positive social change. }\end{array}$ \\
\hline $\begin{array}{l}\text { Stagnant } \\
\text { level }\end{array}$ & $\mathrm{CCC}$ & $\begin{array}{l}\text { Low return on investments. } \\
\text { Negative market outlook. } \\
\text { High threats to market growth potential (supply and demand on the real estate market). } \\
\text { Low potential for economic and spatial growth. } \\
\text { Low self-regulatory capacity, significantly less flexible response to economic changes. } \\
\text { The situation on the real estate market does not foster positive social change. } \\
\text { High discrepancies between the cost and prices of real estate. } \\
\text { The behavior of real estate market actors is likely to be unpredictable. } \\
\text { High threats to the growth of the real estate market. } \\
\text { The situation the real estate market does not foster positive social change. }\end{array}$ \\
\hline Crisis level & $\mathrm{D}$ & $\begin{array}{l}\text { No returns on investments. } \\
\text { The market is stagnant with no prospects for growth. } \\
\text { No potential for economic or spatial growth. } \\
\text { The market is undergoing reorganization. } \\
\text { The price-cost relationship cannot be determined. } \\
\text { The behavior of market participants cannot be predicted. } \\
\text { Very high threats to the growth of the real estate market. } \\
\text { The situation on the real estate market drives negative social change. }\end{array}$ \\
\hline
\end{tabular}


- attract private and institutional investors,

- increase employee mobility,

- contribute to the positive image of a city, municipality or region.

\section{PROPOSED RATING METHODOLOGY FOR THE REAL ESTATE MARKET}

A rating methodology has to be adapted to the specific attributes of a real estate market. A general diagram of a real estate market rating procedure is shown in Fig. 1.

Rating scores are diversified for different market types and market segments at the level of rating variables, i.e. information and factors describing real estate functions. The proposed system has a modular structure to ensure greater methodological openness. A given market can be rated with the involvement of all or selected modules.

In module I, a decision is made to develop a ranking for the real estate market/markets. The project can be commissioned by a third party and/ or performed regularly by a rating agency (on a quarterly, semi-annual, annual or multiannual basis, e.g. when the market collapses).

In this study, we will assume that the rating is performed by a rating agency on an annual basis. In module II, the type and the segment of the real estate market are identified, and the utility function of real estate is determined. Market type is indicative of the utility function of real estate: investment market, commercial market, industrial market, agricultural market, etc. Market segment accounts for a specific group of real estate which is identified in a given type of a market in view of its utility function. Type: investment market $\rightarrow$ segment: residential, services, retail, etc.; type: commercial market $\rightarrow$ segment: retail, services, offices; type: industrial market $\rightarrow$ segment: industrial, warehouse, etc. A real estate market would be very difficult to rate without prior classification. The aim of the proposed division is to introduce a certain degree of uniformity to the rating procedure. The main standardizing factor is the utility function of the market and real estate, which implies that markets will be evaluated based on their utility rather than legal status.

Residential property (apartment) markets in capital cities of Polish regions were rated in this study. The scope of the analysis was determined, the type and segment of the evaluated market were identified and the required data was accumulated. The following sources of information were available: databases of public institutions (databases of the Central Statistical Office, etc.), commercial databases (databases of real estate agencies, etc.), databases of international organizations (e.g. OECD, Eurostat, IMF, etc.), own databases, research and press publications etc.

Module IIIa is related to Module IIIb which identifies the scope of data required for the rating procedure. The following sources of information are available in Poland:

- National Bank of Poland, report on the residential property market in 2011,

- Central Statistical Office, local data bank, 2008-2012,

- Polish Bank Association, AMRON - SARFIN reports,

- Local government rankings published by the Rzeczpospolita daily and the Przekrój magazine, 2010.

Sources of information are adapted to the type of data corresponding to the analyzed market. The classification model proposed in module IIIb (Fig. 2) distinguishes between macroeconomic, mesoeconomic and microeconomic data, and it divides the relevant information into "hard" and "soft" descriptive factors.

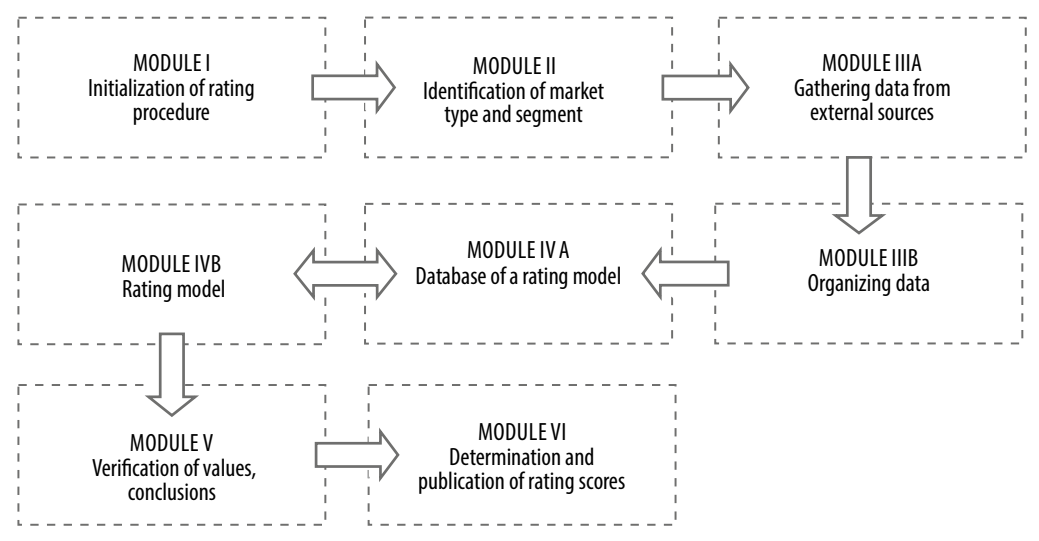

Fig. 1. Diagram of a rating procedure 


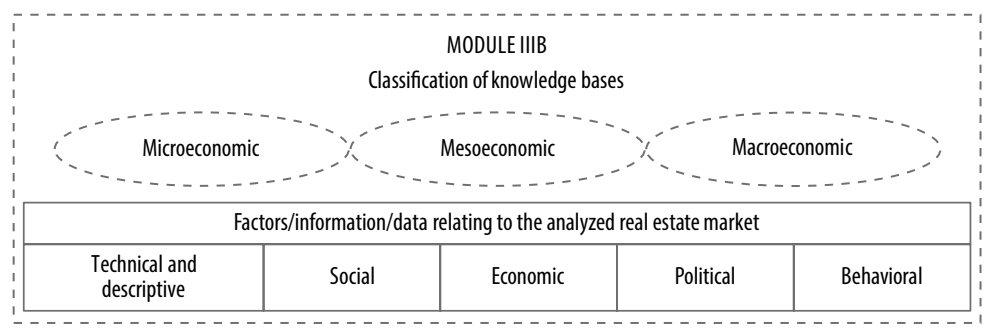

Fig. 2. Module IIIb of the rating procedure diagram

Moreover Kaklauskas et al. (2011) argues that: the analysis mentioned features must be analyzed in an integrated manner to perform an integrated analysis of the life cycle of a crisis in construction and real estate.

An exemplary data set for describing the housing market is shown in Table 2. The presented knowledge base is open, which implies that database components are selected in view of market type, market segment and market outlook.

In the proposed rating procedure, the knowledge database (Table 2) serves as a platform for analyzing the local real estate market. It is also used to build and update databases. The presented information constitutes the knowledge database.

The variables listed in Table 2 constitute essential information which describes the situation on the local real estate market. The range of variables can be modified subject to the size, type and segment of the analyzed market and the purpose of the analysis (investment rating, effectiveness rating). Due to the specific nature of the real estate market, those variables are difficult to quantify and apply in analytical models. Market attributes and variables should be standardized to produce quantifiable indicators. Indicators developed in the proposed analytical procedure should support a comparison of different markets.

Since the main aim of a rating is to provide quick, objective, reliable and updated information, a dataset has to be developed as a platform for quantitative and qualitative analyses. In view of the specific character of the real estate market, the availability of market information and the sudden and unpredictable changes that often occur on that market, the developed system for gathering market data should be flexible enough to enable frequent modifications.

In view of the above, the authors have proposed a "toolkit" for rating the residential property market (Irwin 1993; Jaffe, Sirmans 1986; Bryx, Matkowski 2001; Ball, Wood 1999; Case 2000; Renigier-Biłozor, Wiśniewski 2012b, 2012c). The existing knowledge was compiled to develop a set of indicators for evaluating real estate markets.
The rating toolkit for the residential property market was developed for different categories (Fig. 1) based on the available information. Variables were classified and labeled during the construction of the database presented in a successive module (Table 3).

\section{RATING TOOLKIT}

\section{Residential property market}

Group Ia - political and economic (supply-side) indicators:

- indicator 1a - local government's spending on housing policy (in PLN '000 per person) (in the last four years: 2008-2011),

- indicator $2 \mathrm{a}$ - percent of land covered by zoning plans (percent of land covered by local zoning plans in 2011).

Group Ib - political and economic (demandside) indicators:

- indicator $3 \mathrm{~b}$ - local government's spending per 1 resident in recent years (2009-2011),

- indicator $4 \mathrm{~b}$ - local government's spending on promotion as a share of total expenditures (in the last four years: 2008-2011),

- indicator $5 \mathrm{~b}$ - difference between the national average salary and the average salary on the local market in a given year (2012),

- indicator 6b - unemployment rate (2011),

- indicator $7 b$ - number of new registered businesses (number of new businesses per 1000 residents) (2009-2011).

Group IIa - market (supply-side) indicators:

- indicator 8a - total number of issued construction permits (2012),

- indicator 9a - number of issued construction permits - individual (2012),

- indicator $10 \mathrm{a}$ - number of property offers per 1000 residents (November 2012),

- indicator $11 \mathrm{a}$ - ratio of replacement value per $1 \mathrm{~m}^{2}$ of property to the average price quoted on the local real estate market (2012),

- indicator $12 \mathrm{a}$ - number of property offers average from the most popular websites (November 2012), 
Table 2. Knowledge base of the residential property market

\begin{tabular}{|c|c|c|c|c|}
\hline $\begin{array}{l}\text { Technical and descriptive } \\
\text { factors }\end{array}$ & Social factors & Economic factors & Political factors & $\begin{array}{l}\text { Behavioral/soft } \\
\text { factors }\end{array}$ \\
\hline Price of real estate & $\begin{array}{l}\text { Unemployment } \\
\text { rate }\end{array}$ & Inflation & Real estate tax & Market trends \\
\hline Supply of real estate & Net migration & GDP & Real estate fees & Market trends \\
\hline $\begin{array}{l}\text { Geographic reach } \\
\text { of market }\end{array}$ & Average salary & & Infrastructure projects & Settlement traditions \\
\hline $\begin{array}{l}\text { Population on a given } \\
\text { market }\end{array}$ & Population growth & Mortgage availability & $\begin{array}{l}\text { Planning reports, e.g. } \\
\text { availability of local zon- } \\
\text { ing plans }\end{array}$ & $\begin{array}{l}\text { Individual motiva- } \\
\text { tions driving market } \\
\text { demand }\end{array}$ \\
\hline Number of transactions & \multirow{2}{*}{$\begin{array}{l}\text { Fulfillment of basic } \\
\text { needs, including } \\
\text { - home ownership }\end{array}$} & \multicolumn{2}{|c|}{ Availability of vacant land } & $\begin{array}{l}\text { Prestige associated } \\
\text { with home ownership }\end{array}$ \\
\hline $\begin{array}{l}\text { Purchasing power on } \\
\text { the real estate market }\end{array}$ & & \multicolumn{2}{|c|}{ Development prospects and new investments } & $\begin{array}{l}\text { Fulfillment of person- } \\
\text { al needs and goals }\end{array}$ \\
\hline $\begin{array}{l}\text { Ratio of average replace- } \\
\text { ment value of } 1 \mathrm{~m}^{2} \text { to aver- } \\
\text { age market value of } 1 \mathrm{~m}^{2}\end{array}$ & \multicolumn{2}{|c|}{ Price of fuel (affects urban sprawl) } & \multirow{2}{*}{$\begin{array}{l}\text { Programs that stimulate } \\
\text { demand for real estate, } \\
\text { e.g. subsidized housing, } \\
\text { subsidies for residential } \\
\text { renewable energy }\end{array}$} & Public mood \\
\hline $\begin{array}{l}\text { Attractive location, e.g. } \\
\text { proximity of forests, } \\
\text { parks, water bodies }\end{array}$ & $\begin{array}{l}\text { Prices of energy carr } \\
\text { electricity, gas, coal, }\end{array}$ & $\begin{array}{l}\text { iers, including } \\
\text { etc. }\end{array}$ & & $\begin{array}{l}\text { Speculation on the } \\
\text { real estate market }\end{array}$ \\
\hline \multirow{6}{*}{$\begin{array}{l}\text { Arduous neighborhood: } \\
\text { major roads, railway lines, } \\
\text { industrial plants, etc. }\end{array}$} & \multirow{2}{*}{$\begin{array}{l}\text { Public utilities: uni- } \\
\text { versities, hospitals, } \\
\text { public administra- } \\
\text { tion, etc. }\end{array}$} & \multicolumn{2}{|c|}{$\begin{array}{l}\text { Local authorities' revenues and spending } \\
\text { on housing policy }\end{array}$} & \\
\hline & & $\begin{array}{l}\text { Prices of construction } \\
\text { materials }\end{array}$ & \multirow[t]{3}{*}{ Land use structure } & \multirow{5}{*}{$\begin{array}{l}\text { Implementation of } \\
\text { territorial market- } \\
\text { ing- perceived attrac- } \\
\text { tiveness of the local } \\
\text { real estate market }\end{array}$} \\
\hline & \multicolumn{2}{|c|}{$\begin{array}{l}\text { Number of real estate agencies } \\
\text { and construction firms }\end{array}$} & & \\
\hline & \multicolumn{2}{|c|}{ Job market and job creation } & & \\
\hline & \multicolumn{3}{|c|}{ Internal and external market communication } & \\
\hline & Number of issued c & nstruction permits & & \\
\hline
\end{tabular}

\begin{tabular}{lll}
\hline $\begin{array}{l}\text { Quality of investment } \\
\text { property }\end{array}$ & $\begin{array}{l}\text { Real estate maintenance costs } \\
\text { Changes in real estate market regulations }\end{array}$ \\
\hline $\begin{array}{l}\text { Access to real estate - con- } \\
\text { dition of roads, airports, } \\
\text { railway lines, planned }\end{array}$ & Average salary & $\begin{array}{l}\text { Global economic outlook (credit ratings, demand } \\
\text { for high-risk investments) }\end{array}$ \\
\cline { 2 - 2 } & &
\end{tabular}
railway lines, planned construction projects, e.g. ring roads.

\begin{tabular}{|c|c|c|}
\hline $\begin{array}{l}\text { City's significance in the } \\
\text { region }\end{array}$ & $\begin{array}{l}\text { Number of real } \\
\text { estate agencies }\end{array}$ & Satisfaction with local government \\
\hline Rents & $\begin{array}{l}\text { Real estate revenues } \\
\text { in the municipal } \\
\text { budget }\end{array}$ & $\begin{array}{l}\text { Local government's sup- } \\
\text { port for new investments } \\
\text { and projects }\end{array}$ \\
\hline $\begin{array}{l}\text { Condition of real estate. } \\
\text { Comparison of new and } \\
\text { old property. Comparison } \\
\text { of property on the primary } \\
\text { and secondary real estate } \\
\text { market. }\end{array}$ & $\begin{array}{l}\text { Regional spending } \\
\text { on municipal services }\end{array}$ & \\
\hline Other.... & Other.... & Other.... \\
\hline
\end{tabular}

- indicator $13 \mathrm{a}$ - number of developers on the local market (2011),

- indicator $14 \mathrm{a}$ - affordability of rental housing (number of square meters that can be financed from an average local salary per month) (November 2011),
- indicator $15 \mathrm{a}$ - difference between the average prices of new and second-hand property (1Q 2012),

- indicator $16 \mathrm{a}$ - number of new apartments per 1000 residents (2011). 
Group IIb - market (demand-side) indicators:

- indicator $17 \mathrm{~b}$ - average purchasing power in comparison with the national average - ratio of the average national salary to the average price of property on the local market in a given year (2012),

- indicator $18 \mathrm{~b}$ - number of property transactions per 1000 residents (2011),

- indicator $19 \mathrm{~b}$ - purchasing power on the local housing market (average salary on the local market / average price per $1 \mathrm{~m}^{2}$ of property on the local market) (2012),

- indicator $20 \mathrm{~b}$ - changes in local property prices (2011 - 1Q 2012, average quarterly prices),

- indicator $21 b$ - ratio of replacement value of $1 \mathrm{~m}^{2}$ of property and the average transaction price on the local real estate market (2012),

- indicator $22 \mathrm{~b}$ - average time on the market in months (2012),

- indicator $23 b$ - number of real estate agents on the local market (2011),

- indicator $24 \mathrm{~b}$ - availability of mortgages in terms of $\mathrm{m}^{2}$ (average property price / average credit rating of a family or individual) (2011),

- indicator $25 \mathrm{~b}$ - value of property transaction per 1 resident on the local market (2011).

Group IIIa - social (supply-side) indicators:

- indicator 26a - number of deaths (2011, older than 50),

- indicator $27 \mathrm{a}$ - existing residential area per 1 resident (2011),

- indicator $28 \mathrm{a}$ - number of residents per 1 existing apartment (2011).

Group IIIb - social (demand-side) indicators:

- indicator $29 \mathrm{~b}$ - population density per $\mathrm{m}^{2}$ (2011),

- indicator 30b - number of marriages (2011),

- indicator 31b - number of divorces (2011),

- indicator $32 \mathrm{~b}$ - net migration rate (2011),

- indicator $33 \mathrm{~b}$ - population growth (2011),
- indicator $34 \mathrm{~b}$ - age structure of potential clients $(2011-25-45$ population group vs. total population in a given area),

- indicator $35 b$ - quality of life, measured in terms of the fulfillment of local residents' basic needs (2010-2011):

- nurseries, kindergartens,

- schools, universities,

- quality of transport infrastructure, including road quality, traffic parameters (congestion), internal and external public transport,

- crime rate,

- health care,

- cultural facilities, e.g. cinemas, theaters, museums,

- recreational facilities, e.g. swimming pools, spas,

- recreational areas, e.g. parks, forests, water reservoirs,

- air pollution.

The percentage contribution of toolkit indicators in the entire model is presented in Fig. 3 in view of the number of variables. Market indicators constituted the most significant type of data, followed by social, political and economic indicators. Indicators of market demand emerged as more important than supply indicators.

The construction of the database and the rating model is shown in modules IVA and IVB. The database required for the development of a rating model will be built in phase I. In the analyzed simulation, the above information (indicators and symbols from the rating toolkit) was adapted for the needs of the analytical phase and presented in tabular form.

In phase I, module IVB can be based on models developed with the use of analytical methods, such as regression analysis, geographically weighted regression (Bełej 2011; Cellmer 2010), and advanced
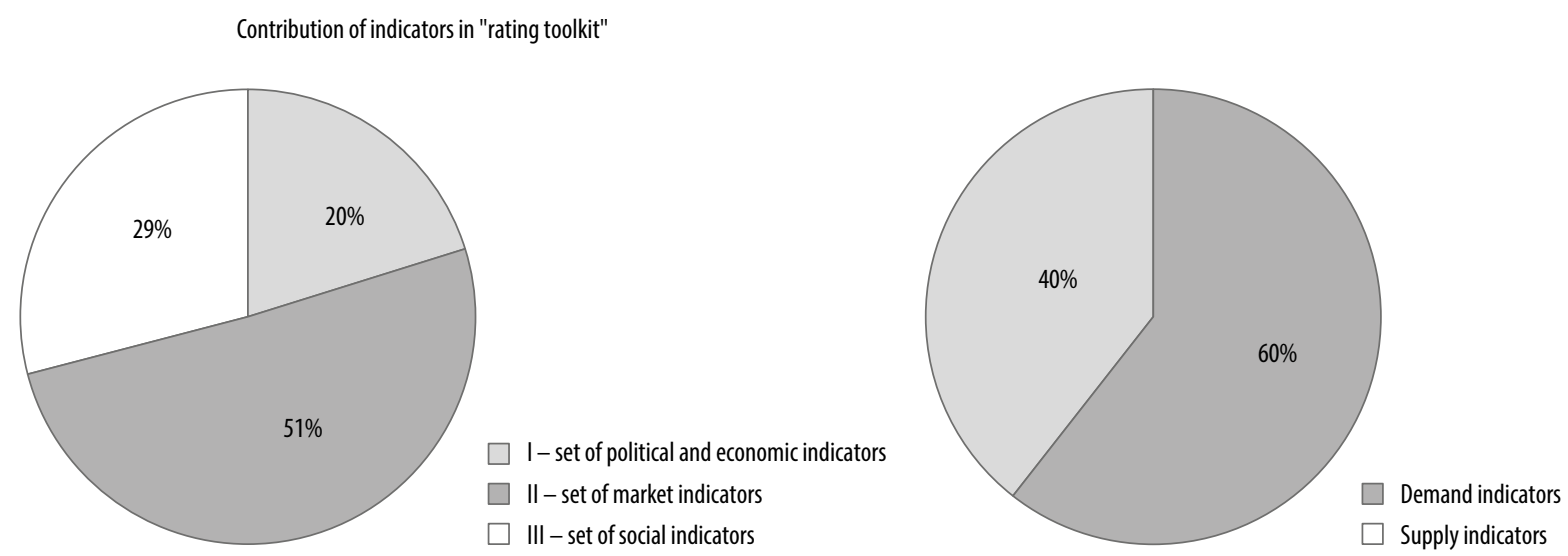

Fig. 3. Share of rating toolkit variables used in analytical models of the real estate market 
methods based on the rough set theory, fuzzy set theory (Biłozor 2005; d'Amato 2009; RenigierBiłozor 2011), neural networks (Wisniewski 2007) and genetic algorithms. Those models are built with the involvement of quantifiable indicators. They are used to develop the decision-making nucleus which will be verified by expert analysis in phase II in view of the available external and internal knowledge bases about the real estate market and its interactions with the outside world. An additional analytical model can be applied to critical and crisis situations, generally referred to as black swan events, which surface earlier in small than in large economies (Olson et al. 2012).

The discussed module allows for unexpected information and events which have different consequences for the real estate market to be accounted for.

\section{ANALYTICAL MODULE}

In the presented simulation, quantitative and expert analyses were used to develop an analytical model of a rating system. A market survey method based on the rough set theory and fuzzy logic was deployed as a quantitative tool for describing market similarities. A statistical analysis involving dendrograms was performed to determine the quality of the examined markets. The expert analysis was used to produce final rating scores.

The proposed rating procedure was used to develop the analytical model. The main analytical model was based on the rough set theory because it will be used to analyze data that is qualitatively and quantitatively ambiguous, imprecise and varied. Pawlak $(1982,1991,1998)$ developed the rough set theory to analyze imprecise and vague data which is commonly found on the real estate market and accompanies decision making (fuzzy decision making) on that market. The theory is used in many sciences, and it is often applied as the main support tool in decision-making systems (Bello, Verdegay 2012; Biłozor 2007; Biłozor, RenigierBiłozor 2009; Chung, Tseng 2012; Polkowski, Semeniuk-Polkowska 2010; Renigier-Biłozor, Wisniewski 2011, 2012a, 2012b, 2012c; Zavadskas, Turskis 2011; Zhang 2012). On the other hand the multiple criteria decision-making method, developed by the authors of this paper, has already been applied for resolving various, construction and real estate sector issues (Kaklauskas et al. 2005, 2006, 2007; Kanapeckiene et al. 2011).

The following analytical procedure based on the rough set theory was used:
- Problem definition - determination of market similarities.

- Development of a decision table - determination of the domains of different conditional attributes (real estate market attributes) and the decision attribute (market) - module IVB.

- Determination of decision rules - Every object $\mathrm{u} \in \mathrm{U}$ in decision table $\mathrm{TD}=$ $(\mathrm{U}, \mathrm{C},\{\mathrm{d}\}, \mathrm{V}, \mathrm{f})$ can be written in the form of a conditional segment (if.... then...), and it can be regarded as a decision rule. In decision table TD, the decision rule comprises functions $\mathrm{g}: \mathrm{C} \cup \mathrm{D} \rightarrow \mathrm{V}$ if $x \in \mathrm{U}$ provides for $\mathrm{g}=f_{x}$. The restriction of $\mathrm{g}$ to $\mathrm{C}(\mathrm{g} \mid \mathrm{C})$ and $\mathrm{g}$ to $\mathrm{D}$ $(\mathrm{g} \mid \mathrm{D})$ is referred to as the conditions and decisions of decision rule $\mathrm{g}$, respectively. In the analyzed case, it has been assumed that the table is deterministic and that that there are 13 decision rules which apply to 13 real estate markets.

- A "valued tolerance relation" (Stefanowski, Tsoukias 2001) is applied to conditional attributes, and the following matrix is created:

$R_{j}(x, y)=$

$\frac{\max \left(0, \min \left(c_{j}(x), c_{j}(y)\right)+k-\max \left(c_{j}(x), c_{j}(y)\right)\right)}{k}$,

where: $R_{j}(x, y)$ - relationship between two sets with membership function [0,1]; $c_{j}(x), c_{j}(y)$ - variable of the analyzed real estate market; $k$ - coefficient adopted as standard deviation for a given real estate market attribute,

- The results produced by the valued tolerance relation matrix of conditional attributes were summed up, and the sum matrix was determined based on the below formula:

$R_{j}(x, p)=\max \left(\sum_{j=1}^{n} R_{j}(x, p)\right)$.

- Preliminary degrees of indiscernibility were determined at a given level of similarity for sets in decision subgroups based on the following equation:

$\mathrm{IND}_{\mathrm{TD}}(\mathrm{B}, \mathrm{d})=\{(x, y) \in U \times U:(x, y) \in$ $\left.\operatorname{IND}_{\mathrm{SI}}(\mathrm{B}) \vee f(x, d)=f(y, d)\right\}$.

- The degrees of abstraction were reduced in view of the repeatability of objects in preliminary decision categories at $65 \%$ similarity. 
At this stage, similar markets were identified at the adopted similarity level, with a division into demand indicators, supply indicators and toolkit indicators.

The results were verified by Ward's cluster analysis. In this method, similar markets are identified by creating $k$-clusters with the aim of minimizing variance inside clusters and maximizing variance between clusters. Distance is measured with Euclidean metrics, and individual cases are assigned to a group whose center of gravity is closest to the analyzed object. The most generalized division into groups was adopted with cutoff value of 20 .

The Rating Team Panel evaluate the listed values and verify the results as part of module $V$. The final rating score of the analyzed market will be determined in this module. In module VI, rating scores will be published by and/or delivered to the party which ordered the rating.

\section{RESULTS}

At the first stage of the simulation process, experts classified the analyzed markets based on key similarities and in view of demand and supply indicators. The above approach was adopted due to different target recipients of the rating and a demand-supply imbalance. This division was also dictated by significant differences in the growth potential of the analyzed real estate markets. The resulting groups of similar markets are presented in Table 3.

Rating scores were determined by the Rating Team (Department of Real Estate Management and Regional Development at the University of Warmia and Mazury in Olsztyn). The gathered material was analyzed and rating scores were determined based on the data shown in Table 1 and the classification of approximate markets.

Rating scores were determined individually for supply and demand due to various market functions and the supply-demand imbalance. The analyzed markets were ranked in ascending order in each category based on toolkit indicators.

A median was determined for each indicator to produce partial rating scores. Numerical values were assigned to every rating score to facilitate calculations: AAA - (1), AA - (2), A - (3), BBB (4), BB - (5), B - (6), CCC - (7), CC - (8), C - (9) and $\mathrm{D}-(10)$.

It has been assumed that the median corresponds to rating score $\mathrm{BB}$. The above decision was made based on the observation that demand still outpaces supply on Poland's emerging real estate market. In respect of selected indicators, rating score BB was shifted irrespective of the median. The results of the analysis revealed that certain indicators ranked significantly below the required level. The above applies to indicator 19b, i.e. average purchasing power on the local market which was below $1 \mathrm{~m}^{2}$, as well as indicators $2 \mathrm{a}, 11 \mathrm{a}, 17 \mathrm{~b}$ and $32 \mathrm{~b}$.

To account for variations within each rating score ("+" and "." signs), intervals were determined within the main categories to determine final ranking scores. Those intervals were set to account for the fact that the calculated "average rating" scores for the main categories (e.g. AAA) do not always equal 1 . The simulation was performed on the assumption that the value of the main rating score (e.g. AA) will "overlap" the neighboring categories by 0.50 .

At the next stage, average rating scores were determined for the analyzed markets by calculating the mean for partial rating scores for demand and supply. The average scores are given in Table 4. For example, the following values were

Table 3. Classification of real estate markets based on key quantitative similarities

\begin{tabular}{|c|c|c|c|c|c|}
\hline \multicolumn{6}{|c|}{ "Approximate" real estate markets according to supply indicators } \\
\hline $\begin{array}{l}\text {-Olsztyn } \\
\text { - Białystok } \\
\text { - Lublin } \\
\text { - Opole } \\
\text { - Zielona Góra } \\
\text { - Kielce } \\
\text { - Rzeszów } \\
\text { - Katowice }\end{array}$ & $\begin{array}{l}\text { - Bydgoszcz } \\
\text {-Szczecin }\end{array}$ & $\begin{array}{l}\text {-Poznań } \\
\text {-Łódź }\end{array}$ & $\begin{array}{l}\text { - Wrocław } \\
\text { - Kraków }\end{array}$ & -Warsaw & -Gdańsk \\
\hline \multicolumn{6}{|c|}{ "Approximate" real estate markets according to demand indicators } \\
\hline- Olsztyn & $\begin{array}{l}\text { - Bydgoszcz } \\
\text { - Lublin } \\
\text { - Białystok } \\
\text { - Katowice }\end{array}$ & $\begin{array}{l}\text {-Rzeszów } \\
\text { - Kielce } \\
\text { - Zielona Góra } \\
\text {-Opole }\end{array}$ & $\begin{array}{l}\text { - Wrocław } \\
\text { - Kraków }\end{array}$ & $\begin{array}{l}\text {-Gdańsk } \\
\text {-Szczecin }\end{array}$ & -Poznań \\
\hline
\end{tabular}


Table 4. "Average rating scores" for the analyzed real estate markets

\begin{tabular}{llllrl}
\hline \multicolumn{2}{l}{ Rating of supply } & \multicolumn{4}{l}{ Rating of demand } \\
\hline Gdańsk & 4.07 & BBB & Gdańsk & 4.52 & BB+ \\
Olsztyn & 6.00 & B & Olsztyn & 5.42 & BB- \\
Szczecin & 4.86 & BB & Szczecin & 5.47 & BB- \\
Bydgoszcz & 6.07 & B & Bydgoszcz & 5.61 & B+ \\
Białystok & 5.50 & BB- & Białystok & 5.71 & B+ \\
Poznań & 4.64 & BB+ & Poznań & 4.80 & BB \\
Warsaw & 3.07 & A & Warsaw & 3.42 & A- \\
Łódź & 5.36 & BB- & Łódź & 5.89 & B \\
Wrocław & 3.64 & BBB+ & Wrocław & 4.76 & BB+ \\
Lublin & 5.28 & BB- & Lublin & 6.19 & B \\
Kraków & 4.00 & BBB & Kraków & 4.67 & BB+ \\
Rzeszów & 5.14 & BB & Rzeszów & 5.42 & BB- \\
Zielona Góra & 5.71 & B+ & Zielona Góra & 5.71 & B+ \\
Kielce & 5.71 & B+ & Kielce & 6.27 & B- \\
Katowice & 5.43 & BB- & Katowice & 5.33 & BB- \\
Opole & 6.36 & B- & Opole & 6.28 & B- \\
\hline
\end{tabular}

determined for Gdańsk (supply): $\mathrm{BBB}-4, \mathrm{~A}-3$, $\mathrm{BBB}-4, \mathrm{BB}-5, \mathrm{BBB}-4, \mathrm{AA}-2, \mathrm{BBB}-4, \mathrm{BB}-5$, $\mathrm{BBB}-4, \mathrm{BBB}-4, \mathrm{~A}-3, \mathrm{BB}-5, \mathrm{BB}-5, \mathrm{BB}-5$, mean $-4.07(\mathrm{BBB})$.

\section{CONCLUSIONS}

The quality of a real estate market rating is a function of its relevance, reliability, usefulness and comparability. Relevance is the rating's ability to assess the current situation on the real estate market based on the available information and knowledge. For a rating system to deliver relevant results, scores have to be developed dynamically. Reliability is the ability to correctly answer questions, search for hidden patterns and anticipate the behavior of market participants. A market rating is useful when it satisfies market participants' need for information. Usefulness determines a given rating system's popularity on the market. Comparability implies the use of uniform rating scales which produce standardized rating scores for the evaluated markets. Rating scores enable market participants to determine whether two markets are comparable.

The simulations based on supply and demand indicators revealed the highest and the lowest performing markets. The best results were reported for Warsaw (capital of Poland) which was given an A score, and the least satisfactory results were noted for Opole in south-western Poland which neighbors highly expansive markets of Wrocław and Katowice. In most cases, rating scores differed in evaluations of market supply and demand, but the noted differences were not significant.

Opole received the lowest score of B- (Table 4), indicating that it is a developing market. Our results indicate that the majority of the analyzed markets have a growth potential. The evaluated markets are regional capital cities with a much higher potential for growth than the remaining Polish urban centers. Our findings also suggest that potential demand on Polish real estate markets continues to be largely unsatisfied.

At the last stage of the simulation process, final rating scores were developed for markets characterized by the greatest quantitative similarities (Table 3). Full rating scores were determined to minimize the impact of the subjective classification of various indicators. Final rating scores in Table 5 were calculated based on median values from the intervals of rating scores presented in Table 4.

Table 5. Final rating scores of real estate markets

\begin{tabular}{|c|c|c|c|c|c|c|}
\hline \multicolumn{7}{|c|}{ "Approximate" real estate markets according to supply indicators } \\
\hline $\begin{array}{l}\text {-Olsztyn } \\
\text { - Białystok } \\
\text { - Lublin } \\
\text { - Opole } \\
\text { - Zielona Góra } \\
\text { - Kielce } \\
\text { - Rzeszów } \\
\text { - Katowice }\end{array}$ & $\begin{array}{l}\text {-Bydgoszcz } \\
\text {-Szczecin }\end{array}$ & $\begin{array}{l}\text {-Poznań } \\
\text {-Eódź }\end{array}$ & $\begin{array}{l}\text { - Wrocław } \\
\text { - Kraków }\end{array}$ & & -Warsaw & -Gdańsk \\
\hline $\mathrm{B}+$ & BB- & $\mathrm{BB}$ & $\mathrm{BBB}$ & & A & $\mathrm{BBB}$ \\
\hline \multicolumn{7}{|c|}{ "Approximate" real estate markets according to demand indicators } \\
\hline- Olsztyn & $\begin{array}{l}\text { - Bydgoszcz } \\
\text { - Lublin } \\
\text { - Białystok } \\
\text { - Katowice }\end{array}$ & $\begin{array}{l}\text {-Rzeszów } \\
\text { - Kielce } \\
\text {-Zielona Góra } \\
\text {-Opole }\end{array}$ & $\begin{array}{l}\text {-Wrocław } \\
\text { - Kraków }\end{array}$ & $\begin{array}{l}\text {-Gdańsk } \\
\text {-Szczecin }\end{array}$ & -モódź & -Poznań \\
\hline $\mathrm{B}+$ & $\mathrm{B}+$ & $\mathrm{B}$ & $\mathrm{BB}+$ & $\mathrm{BB}$ & $\mathrm{B}+$ & $\mathrm{BB}$ \\
\hline
\end{tabular}


The results of our study indicate that rating systems can be developed even for highly non-homogenous markets, including real estate markets. Our findings validate the research hypotheses that a real estate market can be rated in view of its significance for the local and national economy and that real estate market ratings support market participants in the decision-making process.

Real estate markets play an increasingly important role in the global economy and attract a growing number of international investors, which is why the demand for reliable rating systems will continue to grow. Real estate market ratings have three main objectives: to introduce objective criteria for comparing real estate markets within a given reference framework, to contribute to the rationality of the decision-making process and to reduce the number of decision variables. By attaining the above goals, market ratings stabilize the behavior of real estate market participants. Rating systems offer an objective and effective tool for evaluating the performance of a real estate market and predicting future market trends.

\section{REFERENCES}

Altman, E. I.; Saunders, A. 2001. An analysis and critique of the BIS proposal on capital adequacy and ratings, Journal of Banking and Finance 25(1): 2546. http://dx.doi.org/10.1016/S0378-4266(00)00116-3

Altman, E. I.; Rijken, H. A. 2004. How rating agencies achieve rating stability, Journal of Banking and $\mathrm{Fi}$ nance 28(11): 2679-2714. http://dx.doi.org/10.1016/j.jbankfin.2004.06.006

Anglin, P. M.; Gao, Y. 2011. Integrating illiquid assets into the portfolio decision process, Real Estate Economics 39(2): 277-311.

http://dx.doi.org/10.1111/j.1540-6229.2010.00291.x

Ball, M.; Wood, A. 1999. Housing investment: long run international trends and volatility, Housing Studies 14(2): 185-209. http://dx.doi.org/10.1080/02673039982911

Bello, R.; Verdegay, J. L. 2012. Rough sets in the soft computing environment, Information Sciences 212: 1-14. http://dx.doi.org/10.1016/j.ins.2012.04.041

Bełej, M. 2011. Teoria przejść nieciagłych jako metoda modelowania rynku nieruchomości [Theory of discontinous change as a method for modeling real estate market], Journal of the Polish Real Estate Scientific Society 19(1): 59-67. (In Polish)

Beracha, E.; Skiba, H. 2011. Momentum in residential real estate, Journal of Real Estate Finance and Economics 43(3): 299-320.

http://dx.doi.org/10.1007/s11146-009-9210-2

Biłozor, A. 2005. Application of fuzzy logic to the identification and localization of the fringe areas of the city and the village, Acta Scientiarum Polonorum Administratio Locorum 4(1-2): 37-51.
Biłozor, A. 2007. Kształtowanie przestrzeni miasta [The formation of the urban area], Journal of the Polish Real Estate Scientific Society 15(3-4): 57-66. (In Polish)

Biłozor, A.; Renigier-Biłozor, M. 2009. Procedura określania istotności wptywu atrybutów nieruchomości z wykorzystaniem teorii zbiorów przybliżonych [Procedure for determining the significance of the impact of the property attributes using rough set theory]. Przegląd Geodezyjny. (In Polish)

Bryx, M.; Matkowski, R. 2001. Inwestycje w nieruchomości [Real estate investments]. Warszawa: Poltext. (In Polish)

Caporale, G. M.; Matousek, R.; Stewart, C. 2012. Ratings assignments: lessons from international banks, Journal of International Money and Finance 31(6): 15931606. http://dx.doi.org/10.1016/j.jimonfin.2012.02.018

Case, K. E.; Shiller, R. J. 1989. The efficiency of the market for single-family homes, American Economic Review 79(1): 125-137.

Case, K. E.; Shiller, R. J. 1990. Forecasting prices and excess returns in the housing market, Real Estate Economics 18(3): 253-273. http://dx.doi.org/10.1111/1540-6229.00521

Case, K. E. 2000. Real estate and the macroeconomy, Brookings Papers of Economic Activity (2): 119-162.

Cellmer, R. 2010. Analiza przestrzenna dynamiki zmian cen nieruchomości lokalowych $\mathrm{z}$ wykorzystaniem regresji ważonej geograficznie [Spatial analysis of dynamics of changes housing prices with use of geographically weighted regression], Acta Scientiarum Polonorum - Administratio Locorum 9(4): 5-14. (In Polish)

Chin, H.; Dent, P. 2005. An analysis of the level of maturity in South-East Asian property markets, Pacific Rim Property Research Journal 11(4): 355-372.

Chung, W.; Tseng, T.-L. 2012. Discovering business intelligence from online product reviews: a rule-induction framework, Expert Systems with Applications 39(15): 11870-11879. http://dx.doi.org/10.1016/j.eswa.2012.02.059

Collett, D.; Lizieri, C.; Ward, C. 2003. Timing and the holding periods of institutional real estate, Real Estate Economics 31(2): 205-222.

http://dx.doi.org/10.1111/1540-6229.00063

Commission Delegated Regulation (EU) No 447/2012 of 21 March 2012 supplementing Regulation (EC) No 1060/2009 of the European Parliament and of the Council on credit rating agencies by laying down regulatory technical standards for the assessment of compliance of credit rating methodologies, Official Journal of the European Union 55: 14-16. http://dx.doi.org/10.3000/19770677.L_2012.140.eng

CRISIL. 2011. CRISIL Real Estate Ratings [online]. CRISIL Limited. Available at: http://www.crisil.com/ ratings/real-estate-ratings.html [accessed 24 August 2012]

d'Amato, M. 2009. Rough set theory as property valuation methodology: the whole story, in Kauko, T. and d'Amato, M. (Eds.) Mass appraisal methods: an international perspective for property valuers, Oxford: Wiley-Blackwell, UK.

http://dx.doi.org/10.1002/9781444301021.ch11 
D’Arcy, E.; Keogh, G. 1999. The property market and urban competitiveness: a review, Urban Studies 36(56): 917-928. http://dx.doi.org/10.1080/0042098993277

Dziawgo, D. 2010. Credit rating na międzynarodowym rynku finansowym [Credit rating on the international financial market]. Warszawa: Polskie wydawnictwo ekonomiczne. (In Polish)

Fama, E. 1991. Efficient capital markets: II, Journal of Finance 46(5): 1575-1617. http://dx.doi.org/10.1111/j.1540-6261.1991.tb04636.x

Goodman, A. C.; Thibodeau, T. G. 1998. Housing market segmentation, Journal of Housing Economics 7(2): 121-143. http://dx.doi.org/10.1006/jhec.1998.0229

Goodman, A. C.; Thibodeau, T. G. 2003. Housing market segmentation and hedonic prediction accuracy, Journal of Housing Economics 12(3): 181-201. http://dx.doi.org/10.1016/S1051-1377(03)00031-7

Grossman, S. J.; Stiglitz, J. E. 1980. On the impossibility of informationally efficient markets, American Economic Review 70: 393-408.

Irwin, R. 1993. The McGraw-Hill real estate handbook. McGraw-Hill, Inc.

Jaffe, A.; Sirmans, C. 1986. Fundamentals of real estate investment. Prentice-Hall, Inc.

Jones Lang LaSalle. 2012. Global real estate transparency index, 2012. Real estate transparency. Back on track [online]. Jones Lang LaSalle IP, Inc. Available at: http://www.joneslanglasalle.pl/ResearchLevel1/ TransparencyIndex_FINALDRAFT.pdf [accessed 24 June 2013]

Kaklauskas, A.; Zavadskas, E. K.; Raslanas, S. 2005. Multivariant design of multiple criteria analysis of building refurbishments, Energy and Buildings 37(4): 361-372.

http://dx.doi.org/10.1016/j.enbuild.2004.07.005

Kaklauskas, A.; Zavadskas, E. K.; Raslanas, S.; Ginevicius, R.; Komka, A.; Malinauskas, P. 2006. Selection of low-e windows in retrofit of public buildings by applying multiple criteria method COPRAS: a Lithuanian case, Energy and Buildings 38(5): 454-462. http://dx.doi.org/10.1016/j.enbuild.2005.08.005

Kaklauskas, A.; Zavadskas, E. K.; Trinkunas, V. 2007. A multiple criteria decision support on-line system for construction, Engineering Applications of Artificial Intelligence 20(2): 163-175.

http://dx.doi.org/10.1016/j.engappai.2006.06.009

Kaklauskas, A.; Kelpsiene, L.; Zavadskas, E. K.; Bardauskiene, D.; Kaklauskas, G.; Urbonas, M.; Sorakas, V. 2011. Crisis management in construction and real estate: conceptual modeling at the micro-, mesoand macro-levels, Land Use Policy 28(1): 280-293. http://dx.doi.org/10.1016/j.landusepol.2010.06.008

Kalberer, W. 2012. The future of risk analysis in valuation: property and market rating, presentation in the TEGOVA EVS conference, 11-12, May, 2012, Krakow, Poland.

Kanapeckiene, L.; Kaklauskas, A.; Zavadskas, E. K.; Raslanas, S. 2011. Method and system for multi-attribute market value assessment in analysis of construction and retrofit projects, Expert Systems with Applications 38(11): 14196-14207.

http://dx.doi.org/10.1016/j.eswa.2011.04.232
Milewski, P. 1999. Ratingi w gospodarce rynkowej z uwzględnieniem ratingu ubezpieczeniowego [The ratings in the market economy, including the rating of the insurance], Gazeta Ubezpieczeniowa (9-10): 17-26. (In Polish)

Olson, E.; Miller, S.; Wohar, M. E. 2012. "Black Swans" before the "Black Swan" evidence from international LIBOR-OIS spreads, Journal of International Money and Finance 31(6): 1339-1357. http://dx.doi.org/10.1016/j.jimonfin.2012.02.004

Pawlak, Z. 1982. Rough sets, International Journal of Information and Computer Science 11(5): 341-356.

Pawlak, Z. 1991. Rough sets: theoretical aspects of reasoning about data. Dordrecht: Kluwer Academic Press.

Pawlak, Z. 1998. Rough set theory and its applications to data analysis, Cybernetics and Systems: An International Journal 29(7): 661-688.

http://dx.doi.org/10.1080/019697298125470

Pierwszy Ranking Firm Rynku Nieruchomości [First rank of real estate market companies]. 2004. Nieruchomości C.H. Beck, 12(76) grudzień 2004.

Polkowski, L.; Semeniuk-Polkowska, M. 2010. Granular rough mereological logics with applications to dependencies in information and decision systems, Transactions on Rough Sets XII, Lecture Notes in Computer Science 6190: 1-20.

http://dx.doi.org/10.1007/978-3-642-14467-7_1

Regulation (EC) No 1060/2009 of the European Parliament and of the Council of 16 September 2009 on credit rating agencies, Official Journal of the European Union 52: 1-31.

http://dx.doi.org/10.3000/17252555.L_2009.302.eng

Renigier-Biłozor, M. 2011. Analysis of real estate markets with the use of the rough set theory, Journal of the Polish Real Estate Scientific Society 19(1): 107-118.

Renigier-Biłozor, M.; Wisniewski, R. 2011. The efficiency of selected real estate markets in Poland, Acta Scientiarum Polonorum - Oeconomia 10(1): 83-96.

Renigier-Biłozor, M.; Wisniewski, R. 2012a. The impact of macroeconomic factors on residential property price indices in Europe, Folia Oeconomica Stetinensia 12(2): 103-125.

http://dx.doi.org/10.2478/v10031-012-0036-3

Renigier-Biłozor, M.; Wisniewski, R. 2012b. The effectiveness of real estate market versus efficiency of its participants, European Spatial Research and Policy 19(1): 95-110.

http://dx.doi.org/10.2478/v10105-012-0008-5

Renigier-Biłozor, M.; Wisniewski, R. 2012c. Rating rynków nieruchomości - analiza teoretyczna [Rating of real estate markets - theoretical analysis], Journal of the Polish Real Estate Scientific Society 20(2): 59-70. (In Polish)

Stefanowski, J.; Tsoukias, A. 2001. Valued tolerance and decision rules, in Ziarko, W. and Yao, Y. (Eds.) Rough sets and current trends in computing, Lecture Notes in Computer Science 2005: 212-219. http://dx.doi.org/10.1007/3-540-45554-X_25 
Trotz, R. (Ed.) 2004. Property and market rating. Germany: HVB Expertise GmbH.

Wisniewski, R. 2007. Wielowymiarowe prognozowanie wartości nieruchomości [Multidimensional forecasting of the value of a real estate]. Rozprawy i monografie, Olsztyn: Wydawnictwo UWM. (In Polish)

Zavadskas, E. K.; Turskis, Z. 2011. Multiple criteria decision making (MCDM) methods in economics: an overview, Technological and Economic Development of Economy 17(2): 397-427.

http://dx.doi.org/10.3846/20294913.2011.593291
Zhang, Z. 2012. A rough set approach to intuitionistic fuzzy soft set based decision making, Applied Mathematical Modelling 36(10): 4605-4633.

http://dx.doi.org/10.1016/j.apm.2011.11.071

Źróbek, S.; Grzesik, C. 2013. Modern challenges facing the valuation profession and allied university education in Poland, Real Estate Management and Valuation 21(1): 14-18.

http://dx.doi.org/10.2478/remav-2013-0002 